\title{
ТЕАТРЫ-КАБАРЕ: ПУТЬ ИЗ ЕВРОПЫ В РОССИЮ.
}

\author{
Слуцкая Елена Алексеевна \\ Доцент кафедры теории и истории \\ культуры РГПУ им. А.И. Гериена, \\ кандидат искусствоведения.
}

\section{THEATRE-CABARETS. FROM EUROPE TO RUSSIA.}

\begin{abstract}
Аннотация. Автор данной статьи осуществляют попытку осмысления становления и развития артистических кабаре, как одного из доминирующих компонентов развлекательной культуры второй половины XIX - первой половины XX веков. Автор описывает как художественные практики, так и производственноэкономические основания театров-кабаре. Особое место в статье уделяется двум ведущим театрам-кабаре в России: московскому «Летучая мышь» и петербургскому «Кривое зеркало».

Annotation. The author of this article efforts to reflect as stood and developed artist cabarets as first of main forms of recreation culture of second half XIX - first half XX century. The author descriptions as art practices as industrialeconomy basses of theatre-cabarets. An important part of article dedications too main theatre-cabarets in Russia - «Flyer mouse» in Moscow and «Curved mirror» in Sankt-Petersburg.
\end{abstract}

Ключевые слова: театры кабаре, артистические кафе, развлекательная культура.

Key words: theatre-cabarets, artistic café, recreation culture.

Само звучание слова-наименования «кабаре» создаёт образ чередующихся сценических миниатюр, которые по жанровым приемам и характеру содержания ближе всего соприкасаются с эстрадным театром. Но если современное эстрадное представление чаще происходит в традиционном театрально-зальном интерьере, исполнение кабаретной эстрадной программы должно осуществляться «в обстановке ресторана при размещении зрителей за столиками»[2, с. 66], то есть «театр-кабаре в качестве принадлежности искусству эстрады представляет собой исполнение различных номеров - вокальных, танцевальных, речевых, клоунско-цирковых или сценических миниатюр шутливого развлекательного характера не в театральном, а «кафе-ресторанном» пространстве» [16, с. 47].

Театры-кабаре, как и многие другие жанровые разновидности дореволюционной развлекательной культуры, не привлекали особого внимания советских критиков-театроведов. Если даже такой излюбленный всеми новыми (послереволюционными) социальными прослойками жанр как классическая оперетта длительное время считали как «идейно чуждый», и «отживший»[8, с. 7], то театры-кабаре, как, несомненно, враждебный и не нужный новому обществу вид зрелищного искусства, вообще не принимали во внимание. Даже более того, «сопоставляя нередко кабаре с кафешантанами, которые представляли собой увеселительные заведения с открытой сценой и выступлениями с номерами непристойного содержания, театральные критики считали унизительным для себя обращение к подобному сорту зрелищ» [16, с.47]. Следует заметить, что резкие и насмешливые высказывания в адрес кабаре высказывались и в дореволюционное время. Так, выдающимся деятелем искусства и знаменитым художником А.Н. Бенуа было сказано: «Вздумали наши театральные эстеты создать в Петербурге то, чем (уже не первый десяток лет) славился Париж, а для многих русских людей это даже служило главной приманкой Парижа. Я имею в виду парижское «кабаре», то есть то вечно-разнообразное, причудливое, почти всегда дурашливое зрелище, что временами могло принимать характер чего-то обличительного, но что главным образом потешало даже «самых серьезных» людей и что было разбросано по ряду маленьких предприятий на склонах Монмартра»[3, c. 475]. Под «дурашливым зрелищем» понималась программа выступлений «в артистических кабаре, которые первоначально представляли собой импровизированные представления, устраиваемые в литературнохудожественных кафе поэтами, музыкантами, актерами» [16, с. 47], из чего следует, что представители артистической среды и творческой богемы не считали себя недостойными «потешать», а точнее отдавать свой дар и профессиональные умения для создания новой увлекательной художественной платформы.

Зарождение театров-кабаре, как справедливо замечено А.Н. Бенуа, было положено в Париже в эпоху Второй империи, которую связывают с именем племянника Наполеона, объявившего себя Наполеоном III Бонапартом и провозглашенного президентом Второй республики после подавления революции 1848 года. Французская буржуазия, по мнению исследователей, была напугана «движением «четвертого» сословия, пролетариата», но, при этом, «больше всего желавшая сильной власти, сильной во что бы то ни стало и любой ценой, пошла навстречу авантюристу и примирилась с образованием Второй империи» [20, с.54]. Париж стремился быть титулованным как «всемирный центр», и показное великолепие становится одним из путей к достижению данной цели. Театральный историк М. Янковский даже ввел понятие «весь Париж», что означает «своеобразный сплав разношерстного общества - от герцогов, магнатов промышленности и банков до журналистов, актрис, завсегдатаев бульваров («бульвардье»), модных кокоток» [20, с.55]. В этот исторический период - середина XIX 
века, в начале бульвара Монпарнас «некто Бюлье открыл танцевальную площадку. Сад бывшей богадельни с Адской улицы, рю д, Анфер, он превратил в райский сад, высадив здесь тысячу кустов сирени. На очень популярных среди парижан «балах Бюлье» безденежные поэты и нищие студенты могли познакомиться с самыми красивыми гризетками Парижа среди пьянящих запахов сирени. Напротив бального рая стояла старая, полуразвалившаяся станция почтовых дилижансов, последняя при выезде из Парижа в сторону Фонтенбло. Бюлье купил её и открыл в ней кафе «Клозери де Лила», то бишь Сиреневый хуторок». Ко всеобщему удивлению, вскоре «забегаловка эта станет моднейшим кафе Парижа, приютом поэтов» [11, с.160-161]. Подобные заведения развивались с необычайной быстротой, только не в центре Парижа, а на знаменитой окраине - Монмартре. Длительное время Монмартр был пригородом французской столицы, лишь в 1860 году его присоединили к Парижу, но ещё долго этот район «сохранял провинциальный облик. Тишиной, широким горизонтом, открывавшимся с холма, каким-то особенным освещением, а также дешевизной жизни Монмартр привлекал многих художников. Постепенно то тут, то там появлялись мастерские» [12, с.53]. За два года до присоединения к Парижу Монмартр заявил о себе рождением нового театрального жанра - оперетты. Следует, правда, внести уточнение: сначала - в 1855 году, композитор Жак Оффенбах создал маленький театр «Буфф-Паризьен» на входившем тогда в моду городском пространстве - Елисейских Полях. Само название «Буфф» свидетельствует о том, что разыгрывались в этом театре «буффонады, или лирико-комедийные миниатюры, в которых буффонноэксцентричное начало, столь излюбленное молодым пересмешником занимает господствующее место» [20, с. 60]. Под «молодым пересмешником» историк оперетты М. Янковский подразумевает основателя этого непревзойденного театрального феномена - Жака Оффенбаха. Добившись невероятного признания публики и, благодаря коммерческому успеху, Оффенбах со своей немногочисленной труппой смог перебраться на Монмартр, где и состоялась 21 октября 1858 года премьера оперетты «Орфей в аду», означившей рождение нового самостоятельного жанра. После поражения революции 1870 года пустынные холмы Монмартра оживляются многочисленными артистическими кафе. Слияние двух разнородных понятий (еда и искусство) стало возможным вследствие постоянного посещения кафе художниками, а также привлечения в качестве украшения трапезы исполнителей певческих и танцевальных номеров. Уже в 70-е годы ХІХ столетия Монмартр стал представлять калейдоскоп увеселительных заведений, поскольку «в нижней части Монмартра появились такие кабаре, как «Ла гранд пинт», где «встречались писатели и художники» и куда «приходила изысканная публика, чтобы поспорить о литературе, послушать импровизированные выступления поэтов, певцов, музыкантов». А на бульваре Рошешуар, в 1881 году некоему Родольфу Сали удалось бывшее помещение телеграфа переоборудовать под артистическое кабаре, получившем вскоре известность под названием «Ша-Нуар». По мнению художественных исследователей, «у Сали был нюх на талантливых людей». Ему удалось уговорить «группу молодых поэтов и художников, которые именовали себя «гидропатами», покинуть левый берег Сены, где они обосновались в одном из кафе на улице Кюжа, и переселиться на Монмартр»[12, с.66]. Заполняли подобные заведения не одни художники и куплетисты. Посетителями артистических кафе стали «приказчики из галантерейных лавок, девушки на побегушках, прачки, мелкие лавочники, нищие, ремесленники». Простолюдинов привлекала сюда возможность потанцевать «под трубные звуки музыки вальсы и польки или же благопристойную кадриль «посемейному» [12, с.68]. Не удивительно, что Монмартр в это время становится центром артистической богемы и будет впоследствии воспет великим представителем нововенской оперетты Имре Кальманом.

Ещё в 1851 году парижане зачитывались романом «Сцены из жизни богемы» молодого, но быстро завоевавшего известность писателя Анри Мюрже. В романе была описана жизнь обитателей излюбленного студентами ещё с эпохи Ренессанса Латинского квартала. Создатель романа умер рано, не дожив и до сорока лет, но «эта книга - «Сцены из жизни богемы» - вошла в историю французской литературы как её неотъемлемая часть» [7, с.105]. Увлеченный сюжетом романа, в 1894 году итальянский композитор Джакомо Пуччини сотворил свою знаменитую оперу - «Богема». И когда опера была поставлена в Париже, то «французы удивлялись, как удалось итальянскому композитору так хорошо передать поэзию и прозу Латинского квартала, парижских мансард» [7, с.102]. Не одного Пуччини вдохновили страницы романа Мюрже на создание произведения для исполнения на сцене музыкального театра. В 1929 году знаменитый Имре Кальман - автор незабвенных мелодий «Сильвы», «Баядеры», «Марицы» и многих других создает своей последний опереточный шедевр «Фиалку Монмартра», литературной основой для которого послужили также главы романа «Сцены из жизни богемы», но, как следует из названия, место действия переносится с Латинского квартала на холмы Монмартра. Для Кальмана более естественным стало переселить героев своей оперетты - поэта Анри Мюрже, художника Рауля Делакруа, композитора Флоримона Эрве, актрис Нинон и Виолетту из студенческой среды Латинского квартала в художественную среду Монмартра. Как покажет дальнейшее развитие европейской развлекательной культуры, эстетика богемы найдет свое претворение в российских кабаре.

Слухи о доходящем до бешенства успехе парижских кабаре прорвались сквозь границы Франции и с невероятной быстротой донеслись до других европейских государств. Иностранцы стали все чаще посещать Париж с одной только целью - попасть в кабаре. Особенно выделялись среди них немцы. Последнее десятилетие XIX века можно назвать расцветом театрального дела в Германии, отличавшегося многообразием сценических жанров и зрительского адресата. Так, «театральный альманах 1895 года сообщает, что только в одном Берлине 
действует двадцать четыре театра, предлагавших спектакли на все вкусы» [4, с.29]. Королевский драматический театр, существующий на субсидию императорского двора, считался хранителем и законодателем сценических традиций. Репертуарную основу Лессинг-театра «наряду с современными драмами и комедиями, составляли шванки Блюменталя и Кальдебурга» [4, с. 29]. Интерес к буффонаде возрастал в Резиденц-театре. Немало театральных предприятий следовали «скорее коммерческим, нежели просветительским или эстетическим принципам», поэтому для процветания такого театрального дела более необходим «был сад с буфетом, предоставлявший в антракте ублаженным сценой и пивом буржуа возможность подышать свежим воздухом, совершая променад вокруг клумбы». Немудрено, что в этом «задымленном воздухе «литературно облагороженной пивной» легко было принять за авантюриста начинающего Франка Ведекинда» [4, с. 34]. Эпатажный драматург Франк Ведекинд - яростный ниспровергатель жизнеподобия и натурализма в театре, снискавший славу на родине как острый сатирик и борец за новое слово в искусстве, прозванный «дедушкой экспрессионизма», он как никто был вдохновлен атмосферой простоты и художественности французского Монмартра. Германию совершенно справедливо можно считать следующей страной, создавшей все условия для развития новой театральной культуры - театров-кабаре. Русский театральный критик А. Кугель, основатель одного из знаковых театров-кабаре «Кривое зеркало», именно в Германии нашел образец для создания подобных в России: «Во время наших скитаний за границей, мы с 3.В. Холмской посещали частенько так называемые «cabarets». Они тогда были в большой моде, особенно в Германии»[10, с. 195]. На рубеже XIX-XX столетий взошла звезда величайшего деятеля немецкого театра Макса Рейнгардта. В 1898 году заштатный актер Зальцбургского городского театра был приглашен знаменитым Отто Брамом в Берлин в «прославленный Немецкий театр, колыбель сценического натурализма» [4, с. 28]. Но будущему сценическому новатору был чужд иронично прозванный Томасом Манном «пуританский литературный театр», и в поисках подлинной театральности молодой Рейнгардт приходит к пародии. Начало его театральной карьеры в Германии было положено с атаки «на «нетеатральный театр», которая «действительно началась с пародии» [4, с. 29]. После сыгранного вечернего спектакля, Рейнгардт и другие молодые актеры брамовской труппы «собирались в кафе «Метрополь», избранном литературно-художественной богемой в качестве своего штаба». Помимо того, что в кафе «Метрополь» можно было поесть в долг, «в счет будущей славы», прочесть отвергнутое цензурой литературное произведение и найти отклик у отзывчивых слушателей, именно «здесь, в обстановке дружеской раскрепощенности и лихого гаерства, из нескончаемых споров о новом искусстве родилось своеобразное представление - скорее, ряд концертных номеров, в которых каждый старался показать, что смелому не только море по колено, но и все жанры по плечу» [6, с. 35]. Забегая вперед, можно наметить параллель с будущим российским театром-кабаре «Летучая мышь», который через десять лет откроется в Москве охотными до всего нового и дерзновенного актерами МХТа: артисты труппы натуралистического Немецкого театра и артисты труппы «правдивого» серьезного российского МХТ после спектаклей полюбили «отрываться» в ночное время, разыгрывая друг перед другом шуточные сценки-пародии. Объединив вокруг себя с десяток молодых актеров Немецкого театра, Рейнгардт назвал эту труппу в труппе «Очки». Таким образом, наметилась ещё одна параллель с другим российским, на сей раз петербургским театром-кабаре «Кривое зеркало»: очки - кривое зеркало. Несмотря на различие предметной значимости, цель и очков, и кривого зеркала одна - создать приспособления для остроты взгляда. Именно такую идею - «прозревания» видит в создании молодой труппы в труппе российский театральный исследователь С. Бушуева: «Название было символическим: каждого вступающего в её ряды проводили через темную комнату, а затем вручали очки - предполагалось, что с этой минутой новобранец прозревал». Зародившись в «Метрополе», молодая труппа давала представления в одном из домов на улице Унтерденлинден, где «из распахнутых дверей доносилась музыка, а у порога три Пьеро радушно встречали прибывающих»[6, с. 38]. Исполнив роли своих персонажей «в правоверно натуралистическом духе (в частности, сам Рейнгардт в таком именно ключе играл Луку в пьесе «На дне»), перейдя после спектакля в кафе «Шум и гам», «те же актеры давали эстрадные представления, пародировавшие стиль их собственного театра». О пародиях московской «Летучей мыши» будет сказано ниже, а в немецком кафе, например, группа «Очки» разыгрывала перед посетителями «несколько пародий на «Дона Карлоса»: тут были «Карлос» романтический, «Карлос» натуралистический и даже «Карлос» символический, который назывался «Карлос и Элисанда»[6, с. 38].

Искусство кабаре как основополагающее в театральной политике Германии ещё долго культивировало в этой стране, о чем свидетельствует забавный случай. Эмигрировав в 20-е годы XX века в Берлин, уже прославленный к тому времени российский актер Михаил Чехов, приходит к известному антрепренеру, испытывая огромное желание сыграть Гамлета. Актера, находящегося «в праздничном настроении, с маленьким томиком «Гамлета» на немецком языке (был уже выучен первый акт и половина монолога «Sein oder nicht sein») [18, с.147], очень приветливо встречает антрепренер: «Не каждый день приезжают к нам из России Чеховы». Довольный Чехов, желая пленить заготовленной фразой: «Моисси приезжал с Гамлетом в Москву, а я вот в Берлин....ответный как бы визит», был ошеломлен неожиданным вопросом: «Танцуете?». Первые мысли Чехова: «Какие же в «Гамлете» танцы? Фехтование есть...пантомима...Какая неприятная ошибка. Он должен бы знать. - Зачем танцевать? - Мы начнем с кабаре. Я сделаю из вас второго Грока. На инструментах играете? Поете? Ну хоть чуть-чуть? - Простите. Я, собственно...Гамлет...я приехал играть Гамлета... - Гамлет - это не важно. Публике нужно другое» [18, с.148]. 
К концу 20-х годов, в преддверии страшного наступления фашизма, в вихре лихорадочного безумия в Берлине открываются «театры легкого жанра - фарса, комедии, оперетты, мюзик-холла, «обозрений», бесчисленное количество варьете и мелких кабаре». Так, «к 1927 году в столице на пятьдесят один театр (всего десять из которых были драматическими) приходилось девяносто семь варьете» [4, с. 173]. В будущем всемирно известном мюзик-холле «Фридрихштадт-палас», а тогда «в Большом доме для представлений воцарились лихие «герлс» $[4$, с. 173]. Режиссура, актерский образ отменялись, либо сводились до минимума, а сценической доминантной становились тела танцовщиц. «Шестьдесят лиц и одна нога» - такова формула модных номеров, без которых не обходилась ни одна программа» [4, с. 174].

Кульминационной вершиной, сконцентрировавшей в себе дух сумасшедшего развлечения в Германии, явился знаменитый мюзикл Д. Кендера «Кабаре», созданный в 1966 году, но ещё в 30-е годы XX столетия был написан роман Кристофера Иршвуда «Прощай, Берлин», состоявший из нескольких историй-рассказов, один из которых и стал литературной основой сначала для пьесы, а потом и мюзикла. Образ берлинского кабаре времени зарождения нацизма с его скоростной сменой номеров, масок и даже блюд становится символом быстрых перемен в жизни народов, людских судеб и эпох.

К началу XX века победоносное шествие театров-кабаре по Европе достигает России. В Москве, которая к последнему предреволюционному десятилетию представляла собой равнину со свежей взрыхлённой почвой для посева новых ростков культуры, «одно за другим открывались всевозможные кабаре, начали входить в моду «артистические подвалы». Современный исследователь развлекательной культуры Нора Букс называет это время как «особое «золотое» десятилетие, не сравнимое ни с каким другим временем ни по оригинальности и разнообразию форм, ни по числу ярких талантов, ни по самой масштабности обществ праздника искусств» $[5, \mathrm{c}$. 8].

В 1908 году мгновенно при рождении прославились два театра-кабаре - московская «Летучая мышь» и петербургское «Кривое зеркало». «Летучая мышь» была основана двумя деятелями Московского Художественного театра - актером Никитой Балиевым и Николаем Тарасовым - одним из пайщиков театра. Для нового необычного художественно-зрелищного заведения «модные эстеты» (так называли Балиева и Тарасова современники) находят помещение ..... в подвале дома Перцова у Храма Спасителя. Название «Летучая мышь» впрямую не соприкасается с известной опереттой Иоганна Штрауса. Вывеска артистического клуба являла собой олицетворение взлёта, сопровождаемого шумом шуршащих взмахов крыльев, обещая необыкновенное времяпровождение в ночное время суток. Но с опереточным шедевром можно найти сходные черты в веселом озорном характере разыгрываемых сценок, маскарадной атмосфере, бально-танцевальном задоре. Первоначальную репертуарную афишу «Летучей мыши» составляли капустники - театральные сценкиминиатюрки, сюжетной основой которых является легкая и светлая «насмешка какого-нибудь лица или события» [16, с.48]. Современный театрально-драматургический словарь определяет капустники как «внеплановое шуточное представление, обычно приуроченное к определенной дате в истории конкретного театра, юбилею театрального деятеля или корпоративному театральному празднику»[2, с. 116], а из этого следует, что оригинальность капустников заключается в добродушной шутливой иронии «над каким-либо театральным деятелем или театральной историей, хорошо известной всем сидящим в зрительном зале, то есть разыгрывается капустник для «своего зрителя». Следовательно, и участниками сценических представлений, и посетителями «Летучей мыши» были артисты и работники МХT, или его друзья и постоянные зрители. То есть, произошла «отмена зрителя, как основного театрального компонента» [16, с. 49].

Во время разыгрывания капустников как шутливо-пародийных сценок, осуществлялся метод «передразнивания» популярных актеров труппы МХТ - Лужского, Москвина, Качалова и даже самого Станиславского. Из этого напрашивается ещё один вывод: происходило «отчуждение собственного творческого лица», или «сценическая двуличность»[16, с. 49].

В столь уникальном зрительском формате «для своих» «Летучая мышь» просуществовала совсем немного лишь четыре года. Недолговечная история учреждения-феномена вновь продемонстрировала победоносность материально-экономического «базиса» над художественной «надстройкой». Уже к концу августа 1912 года «интимный клуб актеров МХТ превратился в коммерческий театр» кабачка», то есть изменения в новом театре коснулись в первую очередь коммерческого основания - организацией продажи билетов. Несмотря на то, что посещение театра стало дорогостоящим удовольствием, «Летучая мышь» продолжала пользоваться огромной популярностью и приобрести недешевый билет было непросто. Именно в это время начинающий актер МХТа Евгений Вахтангов успешно поставил в кабачке музыкально-танцевальный номер «Оловянные солдатики». А в послереволюционную эпоху, можно сказать, «история модного дореволюционного театра-кабаре почти завершилась» [17, с. 491]. Уже осенью 1918 года Балиев покинул Россию, перебравшись с оставшейся небольшой частью труппы в Турцию, а затем в Америку. Большой неожиданностью для мхатовцев, гастролирующих в 1922 году по Соединенным Штатам, было увидеть на крыше одного из небоскрёбов исполнение вахтанговских «солдатиков».

Десятилетняя художественная практика московской «Летучей мыши» не прошла бесследно для истории русского театра. Её несомненные заслуги заключаются в том, «что в России: 1. впервые появляются 
артистические клубы; 2. положено начало жанра театральной пародии; 3. произошло зарождение сценической миниатюры как самостоятельного театрального жанра» [16, с. 51].

Театральные историки издавна отмечают существовавший антагонизм двух столиц - Москвы и Петербурга. О строгом и суровом Петербурге говорили, что он «с его широкими проспектами был городом чиновников и аристократов». А «живописная Москва, с его кривыми и узкими переулками - городом мещан, купцов и предпринимателей»[15, с. 27]. Особо подчеркивали, что «Москва была серьёзна и смела в своих увлечениях»[15, c. 28]. И, если такое легкомысленное «увлечение» как клуб Балиева, столь быстро завоевавшее популярность, было естественным и понятным явлением для Москвы, то ситуация его незамедлительного продолжения в чопорно-аристократическом Санкт-Петербурге могла вначале показаться парадоксальной и вызывать недоумение. Более того, если французские артистические кабаре размещались на небогатых улицах Монмартра, московское артистическое кабаре «Летучая мышь»- в полутемном подвале, то петербургские театры-кабаре нашли свое прибежище в...прославленных домах знатных сановников и вельмож, где продолжали царить «напыщенность и холод изрядно одряхлевшего имперского ритуала»[15, с. 26]. На подмостках Театрального клуба, размещавшегося в доме князей Юсуповых на Литейном проспекте («это было самое «вельможное» здание»[9, с.32]) 6 декабря 1908 года в один вечер открылись два театрика малых форм: «Лукоморье» под руководством уже известно нашумевшего В. Мейерхольда и «Кривое зеркало», основателями которого стали артистка Суворинского театра Зинаида Холмская и её муж, театральный критик Александр Кугель. Роскошный дворец, в котором «обосновался Театральный клуб», Николай Евреинов - известный режиссер, описал как: «темно-серый дом с графитным оттенком, почти сплошь мраморный, с огромным высеченным подъездом», который «восхищал меня и настораживал отъединенностью от прочих зданий, тесно к нему примыкавших и казавшихся рядом с ним архитектурными плебеями. Словно этот дворец князя Феликса Юсупова графа Сумарокова-Эльстон всем своим видом надменно говорил прохожим, что он ничего общего не имеет с окружающими его домами» [9, с. 32]. Более ироничную, но не упускавшую эпитет «великолепия», характеристику дал дворцу А.Н. Бенуа. Дом на Литейной в его описании «имел очень затейливый фасад, весь из серого камня высеченный, внутри же он был отделан по изысканнейшей моде «Второй империи», иначе говоря - с вызывающей роскошью»[3, с. 475].

Прославленному своей древнейшей родовитостью, несметным богатством, а также достойными заслугами на благо Отечества великосветскому семейству князей Юсуповых в одном только Петербурге, помимо основной резиденции на Мойке (Большого Дома) принадлежало ещё несколько зданий. Описания уже упомянутого режиссера Николая Евреинова свидетельствуют, что «после революции 1905 года многие из российских вельмож пораспродали свои родовые имения; немало из них уехало за границу, сдав в аренду, почти за бесценок свои «исторические» владения» [9, с. 37]. Красивый и богатый, блестящий и независимый Феликс Юсупов, продолжавший жить с семьёй в России вплоть до 1919 года, сдал Театральному Клубу свой особняк «почти задаром, взимая с Союза чисто символическую плату» [17, с. 37]. Для союза драматических писателей была выгодна организация театрально-зрелищных коллективов как дополнительный источник существования и как сохранение статуса культурно-художественного центра. Поэтому, идея Зинаиды Холмской устройства нового театра-кабаре, непохожего на уже существовавшие сценические формы, пришлась по вкусу учредителям союза. Российские театральные и художественные деятели уже были наслышаны о нашумевших на Западе театрах пародии и гротеска, «но именно первым артистическим кабаре в Петербурге была отведена роль художественной огранки, кристаллизации театральной пародии»[16, с. 52]. И, тем не менее, рождение нового театрального явления не избежало критического взгляда. Александр Бенуа, посетивший первые представления в доме Юсуповых на Литейном, отметил не без свойственной ему доли иронии и сарказма: «Когда кабаре стало действовать», то публику «пускали лишь по роскошной беломраморной лестнице, ведшей от вестибюля прямо в большой квадратный танцевальный зал. Там и был устроен кабацкий театрик»[2, с. 476] . Не известно, мог ли выдающийся деятель искусств А.Н. Бенуа предполагать, что такие имена, как любимой сегодня многими читателями писательницы-юмористки Надежды Тэффи, композитора Ильи Саца, создавшего незабвенные мелодии к «Синей птице» в Московском Художественном театре, эпатажно нашумевшего режиссера Николая Евреинова начнут своё пышное цветение в «кабацком театрике». Первоначальную труппу изначально составили актеры петербургских театров: Суворинского (3. Холмская, С. Антимонов), Комиссаржевской (А. Лось, В. Хенкин, Е. Нелидова), «но уже вскоре доступ к сценической площадке нового театра был открыт всем желающим» [16, с. 53]. Сразу же «потянулись любители, в особенности студенты, никогда и нигде не выступавшие и потому готовые работать бесплатно» [17, с. 59]. Молодежная группа, как это обычно происходит, привнесла на сцену освежающую атмосферу, дополняя представления приёмами импровизации и имитации. Так, «один из них неподражаемо имитировал испорченный граммофон, другой - с удивительной точностью передавал звуки валторны, третья - изображала якобы записанное на пластинке чтение М. Савиной, В. Стрельской и других известных актрис Александринского театра» [17, с. 60].

Название «Кривое зеркало» организаторами театра было выбрано не случайно. Увидевшие вывеску зрители могли вспомнить новеллу ещё юного Антона Павловича Чехова, более известного под псевдонимом Антоша Чехонте. Главный герой рассказика - старинное зеркало, обладавшее невероятными свойствами - искаженно 
отражать черты человеческого лица, в результате которого симпатичное личико становилось смешным и уродливым, а некрасивое лицо, несколько искривившись, преображалось в прекрасное. Таким образом, идея чеховского святочного рассказа - «минус на минус дает плюс» легла в основу художественной концепции новообразованного театра миниатюр - методом пародийного высмеивания творить Красоту. Жанровым лицом театра можно назвать художественную пародию, а целью - создавать прекрасные произведения искусства из отрицательных черт предмета. Так, смело и дерзко взлетев на сценические подмостки более ста лет назад, пародия прочно утвердилась в современном театре эстрады.

Доминантой успеха «Кривого зеркала», «перлом театральной пародии» признан спектакль «Вампука, или Принцесса Африканская». Уникальность этого сценического действа удвоена тем, что название спектакля «Вампука» преобразовалось в термин, применяющийся с тех пор на оперной сцене. В профессиональном лексиконе деятелей музыкального театра оперное неправдоподобно-фальшивое исполнение обозначается одним словом: «вампука», «вампучить». Так, «вместо того, чтобы говорить певцу: «Это неестественно, стали говорить: «Это как в Вампуке», если певица не желала петь полулежа или на втором плане сцены, её стали стыдить той же «Вампукой» (мол, это лишь в «Вампуке» примадонна поет непременно у рампы и обязательно стоя); если хор механически жестикулировал, над режиссером смеялись: «Это же чистейшая «Вампука!». Ругательнокритический смысл «вампуки» достался и сценографам в тех случаях, когда «художник-декоратор обрамлял с условной роскошью то или иное место действия, ему выговаривали: Это как-никак не «Вампука» [9, с. 76]. Таким образом, «в результате своего ошеломительного успеха «Вампука» стала магическим словом, от которого сразу же зашаталось и рухнуло трафаретное оперное искусство, чтобы дать место противоположному, творчески оригинальному, а главное, елико возможно, естественному и убедительному искусству». О происхождении названия пародийного спектакля можно узнать из рассказа князя Михаила Волконского своей родственнице, мол как-то «чествовали в Смольном институте престарелого герцога Ольденбургского и хор воспитанниц с цветами пел ему на известный мотив из «Роберта»: - Вам пук, вам пук, вам пук цветов подносим....Она его спросила: Разве есть такое имя, Вампук? Сначала никто не понял. Но потом сообразили, что девица слила два слова в имя собственное. Волконский ответил ей: - Неужели вы не знаете? Вампук - это обыденное имя. И женское есть. Вампука. Очень звучные имена» [9, с. 83-84]. Таким образом, из обыденной шутки «создалось прозвище, ставшее крылатым, и теперь ничем уже не вытравить его из театрального обихода» [9, с. 84]. В 1898 году Волконский напечатал этот пародийный фельетон в «Новом времени». Красочное описание спектакля приведено Г. Крыжицким в статье «Лаборатория смеха», процитированной исследователем М. Поляковой: «Африканская пустыня, посреди которой роскошная, обитая красивым плющем кушетка. Две-три намалеванные на фанере пальмы. Четыре статиста, бог знает как размалеванных, изображают хор; в рыжих трико и с огромными фиговыми листами они пели: «Мы в пу-, мы в пу-, в пустыне мы живем. И как -, и как-, и кактусы жуем» [14, с. 34]. Главного героя - Лодырэ исполнял артист Л. Лукин, который уже своей внешностью - «маленький, кругленький, толстенький» производил необычайно «комическое впечатление», дополняя пародийный образ остроумным утрированием певческих приемов школы брель-канто. А артист Л. Фенин, работая над созданием пародийного характера оперно-величественного эфиопского царя, задумал «живописно и горделиво - по-шаляпински опираться на небо и обмахиваться носовым платком, который он доставал из своего африканского тела коричневого трико» [14, с. 34].

В 1910 году на новообразованную должность главного режиссера в «Кривое зеркало» был назначен Николай Евреинов, называвший место своей новой работы «эшафотом, где была выставлена на всеобщее осмеяние вся современная зрелищная культура во всех её направлениях и разветвлениях от «низших» - шантана, фарса, оперетты, кинематографа, до высших - оперы, балета, вплоть до симфонической и хоровой музыки» [17, с. 270]. Введенное им понятие эшафот надо воспринимать «как «обезглавливание», то есть лишение, ликвидация (в данном случае - осмеяние) основного стержня всех вышеизложенных театральных видов»[16, с. 55]. Но сутью пародии Евреинова, его «основным предметом пародирования на сцене «Кривого зеркала» становились жанры и направления искусства, давно окостеневшие, пережившие свои лучшие времена» [17, с. 272]. Творческим лицом Евреинова в «Кривом зеркале» следует признать поставленную им в 1913 году сатирическую пьесу «Гастроль Рычалова». Идейной концепцией этого спектакля является пародийное высмеивание псевдоклассической игры провинциальных актеров-трагиков. По мнению исследователя Л. Тихвинской «она превзошла даже «образцовую оперу» «Вампуку» [17, с. 275], а «приход Н. Евреинова в «театр пародии и сатиры был закономерным», поскольку именно «пародии для Евреинова были средством и способом разрушения художественного языка старого театра и, одновременно, тем сценическим материалом, куда он вводил новую театральную лексику»[17, с. 275].

Вскоре «Кривое зеркало», выйдя из структуры Театрального Клуба, и, покинув Дворец Юсуповых на Литейном, «перестало существовать в качестве кабаре» и, сделавшись самостоятельным театром, перестало довольствоваться литературными и театральными пародиями. Занимаясь постановками одноактных драм, уникальный «дивертисментный» театр-кабаре был преобразован в обычный репертуарный театр.

Значение «Кривого зеркала» в истории и культуре российского театра можно определить следующими аспектами: 
- было «положено начало процессу обновления художественного оперного языка - постепенному отказу от оперно-сценического шаблона» [16, с.56], в результате чего в России утвердился театр пародии

- было «положено начало неканоническим формам искусства»[16, с.56], в результате чего в России произошло утверждение двигателя «театрального прогресса» для его дальнейшего продвижения

- было положено в России начало новой театральной формы - театра миниатюр, послужившего прообразом для зарождения будущего эстрадного искусства.

\section{Список литературы:}

1. Анри-Сафье Э. «Веселые вечера» «художественников»: о капустниках МХТ в первое десятилетие ХХ века // Русская развлекательная культура серебряного века 1908-1918. Научное издание. Издательский дом высшей школы экономики. 2017. С. 249-274.

2. Баканурский А., Овчинникова А. Современный театрально-драматический словарь. Одесса. Студия «Негоциант». 2007. 334c.

3. Бенуа А. Мои воспоминания. Т.2. Изд. второе, дополненное. М. Наука. 1990. 743c.

4. Бояджиева Л. Рейнхардт. - Л. Искусство. 1987. 222с.

5. Букс Н. Вводный очерк // Русская развлекательная культура серебряного века 1908-1918. Научное издание. Издательский дом высшей школы экономики. 2017. С. 8-16.

6. Бушуева С.К. Моисси. Л. Искусство. 1986. 189с.

7. Данилевич Л. Джакомо Пуччини. М. Изд. Музыка. 1989. 453c.

8. Дрейден Сим. За оперетту (О книге и её авторе) // Янковский М.О. Искусство оперетты. Вступительная статья. М. Всесоюзное издательство «Советский композитор». 1982. С. 3-17.

9. Евреинов Н. В школе остроумия. Воспоминания о театре «Кривое зеркало». М. Искусство. 1998. 366c.

10. Кугель А. Листья с дерева. Изд. Время. Л. 1926. 209с.

11. Носик Б. Прогулки по Парижу. Левый берег и острова. М. ОАО Радуга. 2001. 343c.

12. Перрюшо А. Жизнь Тулуз-Лотрека. М. Радуга. 1990. 284c.

13. Полякова М.Я. Русский театр в кривом зеркале пародии // Русская театральная пародия XIX - начала XX века. Вступит статья. М. Искусство. 1976. С. 6-39.

14. Рудницкий К. Мейерхольд. М. Искусство. 1981. 424c.

15. Рудницкий К. Русское режиссерское искусство 1898-1907. М. Наука. 1989. 384c.

16. Слуцкая Е.А., Почуйко О.В, Хведченя А.А. Театр-кабаре в дореволюционной России и его жанровое своеобразие // Общество. Среда. Развитие. 2020. № 1. С. 47-56.

17. Тихвинская Л. Кабаре и театры миниатюр в России. 1908-1917. М. РИК Культура. 1995. 527с.

18. Чехов М. Путь актера: жизнь и встречи. М. АСТ. 2009. 554c.

19. Эфрос Н.Е. Театр «Летучая мышь» Н.Ф. Балиева. Обзор десятилетней художественной работы первого русского театра-кабаре. Петроград. 1918.

20. Янковский М.О. Искусство оперетты. М. Изд. Советский композитор. 278c. 